KENTE, 2019,

Vol 1, No. 1, 59-73

\title{
The Making of the New Man in Contemporary African Fiction: A Reading of
}

\section{J.M. Coetzee's Disgrace}

\section{Christabel Aba Sam}

Department of English

University of Cape Coast

Cape Coast, Ghana

christabel.sam@ucc.edu.gh

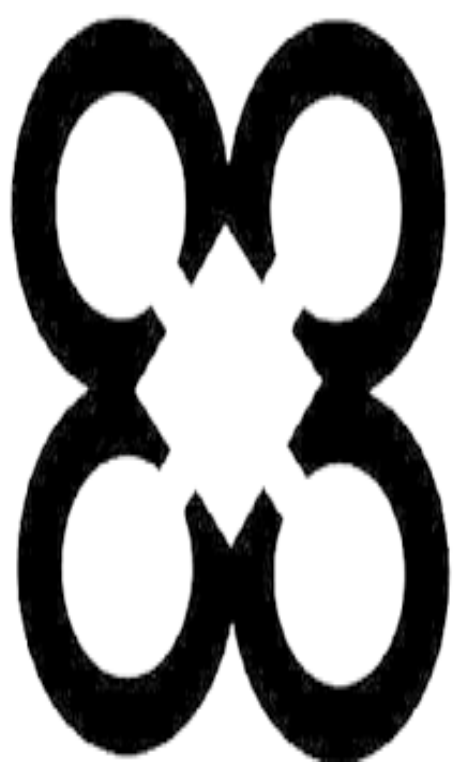

\section{ABSTRACT}

Critical works on Coetzee's Disgrace shows that the novel constructs a distressing picture of the conditions in postapartheid South Africa -tabling his attempts at blurring national enthusiasm, creating racial stereotypes and consequently damaging the hopes of the new South Africa. However, a re-reading of the novel reveals that the survival of post-apartheid South Africa reside in the potential of a willing unity of racial bodies and a careful re-definition of masculinity vis-à-vis spatial reconfigurations. Drawing on the concept of futurity and Frantz Fanon's idea of the new man, this paper argues that the correlation between forms of community and forms of masculinity provide basis for re-configuring social cohesion in post-apartheid South Africa.

\section{KEYWORDS}

Coetzee, Disgrace, Masculinity, Futurity South Africa, Spatial Dynamics 


\section{Introduction}

In this paper, I demonstrate how Coetzee's Disgrace contributes to the discourse on emerging masculinities taking into consideration the history of South Africa. Of crucial essence as far as the concerns of this paper are concerned is the re-examination of the characters of David Lurie, the protagonist, and Petrus, the black peasant. While several scholars continue to make interesting observations regarding the life of the main character, David Lurie, how he has no relationship of depth with men (Kochin, 2002), how he represents the threatened Whites in South Africa (Du Pisani 2001), and how he provokes issues of sexual minorities and male dominance (Graham, 2003), my examination of Lurie and Petrus' character roles will accentuate Coetzee's vision of the new man and how this vision corroborates his attempt at healing the binaristic tensions in post-apartheid South Africa.

Disgrace (1999) is a story about a 52- year old white professor of English at the University of Cape Town, David Lurie; a divorcee (having married twice) with a daughter, Lucy. Lurie has not had such a good relationship with women. After feeling dejected and disappointed by Soraya (a Muslim prostitute), he still goes about thinking that he owes women's beauty and so made it a point to lure Melanie (one of his students) into his bed. Melanie succeeds in bringing out the young and the vulnerable side of Lurie. While he is lost in excitement, the affair with Melanie leads to David Lurie's expulsion from the university since he had blatantly refused to succumb to the demands of the investigating committee that was responsible for investigating the complaint brought against him by Melanie. His expulsion from the university compels him to move to his daughter in the Eastern Cape. There, he is witness to a brutal scene in which he is severely burned, while his daughter is raped by three black men. David is shocked when he finds out his daughter was raped, but Lucy remains calm: she does not want to confess to the police. Throughout the story David and Lucy continue to argue about the violence in South Africa. Lucy however remains silent and does not want to talk to her father about this. As a sort of cure, David decides to work in an animal clinic. There, he meets Bev Shaw, with whom he discusses Lucy's situation and with whom he decides to have sex again. In the end, David reaches a feeling of absolution, because his care for the dogs takes his thoughts away from his daughter.

The paper is structured into three main parts. The first part is under the sub-theme, 'PostApartheid Writings and Disgrace'. Here, I examine the transformative potential of post-apartheid writings in general and Disgrace in particular. The second section, which is themed, 'White Men, Black Men; Coetzee's Disgrace and the making of the New Man, I examine Coetzee's propositions on the characteristics of the 'new African' using Frantz Fanon's concept of the new man. While the third section discusses how spatial dynamics become significant in the transformation project of Africa, under the title, 'This Place called South Africa: Spaces of 
Shame and Pride, the fourth and final section examines how hope is located in masculine reformations under the sub-theme; 'Refiguring Hope and Desire: Masculinities in Transition'.

\section{Post-apartheid writings and Disgrace}

South Africa in the late 1990's, after the abolition of the apartheid regime and after the first democratic elections was boiling with a supposed optimism, which sought to make stable the disorder, segregation and alienation and by so doing uncovering the content of the new South Africa. The new South Africa, celebrated as the 'rainbow nation' ordinarily suggests a cohesion between used-to-be racial categories, gendered subjects and cultural and religious units. Indeed, there was a move towards community. Nonetheless, writings within the post-apartheid era proffer bifocal perspectives. While Crous (2005) observes changes in the gendered ordering of society and how new ideals of human dignity are achieved, how the past plays a role in shaping the present as the concern of black South African writers, Attwell and Harlow (2000) acknowledge exorcising the present of its enduring trauma as the concerns of white South African writers. While these positions stand, Pechey (1998) contends that post-apartheid writings ought to: Tell stories which open out to transform the victory over apartheid into a gain for postmodern knowledge, a new symbiosis of the sacred and the profane, the quotidian and the numinous (P.58).

J. M. Coetzee re-examines intimate historical issues and how they signal an impulse for newness. Disgrace is set in post-apartheid South Africa. The novel engages with a number of issues, including the effects of colonization and the deforming impacts of apartheid. The novel exposes the racial oppression of blacks in South Africa, the implications of place and land ownership as well as highlighting the themes of power and otherness in South Africa. Although some critics consider Disgrace unenthusiastic about the new South Africa, (Kok, 2008; Opheim, 2016), in terms of how the narrative appears to favour the plights of the Whites in South Africa, Coetzee's novel opens up possibilities rather than closing down the discussions. As we may find in the inversion of Lurie and Petrus, Coetzee does not present an oblique picture of the new South Africa. What he does is to stir up the options available for restoring human dignity.

Quite a lot of critics have looked at Coetzee's Disgrace from several intellectual perspectives. Karworska (2013), for instance, looks at the textual strategies Coetzee employs in signaling the essence of place. She argues that the allegorical orientations of place in Coetzee's fiction are representative of a large idea or as a universal construct capable of carrying the echoes of colonial and post-colonial socio-political circumstances (p.4). Graham (2003) on the other hand interrogates the volatile nature of the subject of rape in Coetzee's Disgrace.

She argues that the novel performs a subversion of 'Black Peril' and suggests that such presentations potentially play on White paranoia and obscures the fact that most rape cases in South Africa are interracial. In Age of Bronze, State of Grace: Music and Dogs in Coetzee's Novels, Attridge (2000) claims that Coetzee presents a bleak image of the 'new' South Africa although he admits the fact that the novel deals with the relationship between racially defined groups. He however contends that the altered worlds Coetzee presents ushers in new ages - from a dangerous age to puritanical times to an age of painful awakening. Even though the bulk of these debates find connections with the current project, my focus in this paper will be to explore the masculine representations in Coetzee's Disgrace paying particular attention to how the idea 
of the 'new' man is configured through the dynamics of space and how they compel a futuristic impulse. It also looks at how hope and desire are reconfigured through interpersonal relationships and how they usher in the anticipated social cohesion in post -apartheid South Africa.

\section{White men, Black Men: Coetzee's Disgrace and the making of the New Man}

The concept of the 'new man' is at the heart of Frantz Fanon's vision of the future of independent nations (Lazreg, 2007). Fanon (2002) argues that Africa's contact with the West during the colonial era brewed a certain kind of falsehood as far as issues of identity are concerned. He further argues that the black man was forced to disown his heritage and violently coerced into accepting a different kind of reality so that there is a certain degree of pathological betrayal of blackness. In other words, Africa's contact with the West placed an ideological hold on the mindset of the black man and therefore the black man is reluctantly immersed in European consciousness - 'selfishness, recriminations born with conceit and the infantile silliness of always wanting to have the last word' (Fanon, 2002:48 as cited in Lazreg, 2007:19) as opposed to the communal and pluralism in pre-colonial civilization.

Consequently, Fanon suggests that in order to re-assert the dignity of the black identity, there ought to be born the 'new man' - a process that requires what he refers to as 'pacification', a kind of decolonization and mental cleansing. In other words, the 'new man' must break loose from the ideological hold of western influence and move toward feelings of community, taking responsibility for the shame associated with the African identity and radically de-affirming the superiority of whiteness. Thus, according to Fanon the "'new man' can only emerge out of a consciousness that has been able to demystify the colonial ideology of obfuscation that hides before eternal essences (p. 49).

Simply, the 'new man' must be defined by a new consciousness - a consciousness that rejects and abandons the restricted meanings associated with black identity. A consciousness that is 'actionnel'-agentic, radical and productive. In other words, the 'new man' must show tough resistance to all forms of ideologies that are imperialistic and prejudiced. In the world of Coetzee's Disgrace, we recognize the potential of a new beginning through black resistance and the racial transformations when we juxtapose Petrus and David Lurie as important male figures. David Lurie earns his living at the Cape Town University College as a Professor in Modern Languages and Communications. He is a two-time divorcee with a daughter. Fifty-two year old David Lurie appears to have solved the problem of sex rather well. In the opening scenes of the novel, we are introduced to David Lurie as:

For a man of his age, fifty-two, divorced, he has, to his mind solved the problem of sex rather well. On Thursday afternoons, he drives to Green Point punctually at two pm. He presses the buzzer at the entrance to Windsor Mansions, speaks his name, and enters. Waiting for him at the door of No. 113 is Soraya.... He strokes her honey brown body, unmarked by the sun; he stretches her out, kisses her breasts; they make love' (p. 1).

David Lurie is a reckless man. For a two-time divorcee, Lurie is not in the least circumspect about his relationships. He has always found it easy to seduce women and as he ages, he loses this quality more and more and he refuses to realize this. He takes refuge in his poetic lines and assumes he is still on top of his game. Soraya, a Muslim prostitute, is just one of 
his conquests. David Lurie is portrayed as self-absorbed in his dealings with others. Indeed, it is in his nature to reduce women to nothing especially the ones he considers super-inferior. To think that he considers ninety minutes a week of a woman's company better enough to make him happier than to need a wife, a home and/or a marriage is enough to tell how complacent and imprudent he is in emotions. He seems in control of his own life; having the liberty to have illicit affairs with whomever he chooses. Womanizing has become his thing and he exists 'in an axioms flurry of promiscuity' (p.7). He engages in sexual relationships with the wives of his colleagues. Dawn, the secretary at his Department, Soraya and his two unsuccessful marriages are examples. He cannot bring himself to retire from such games; he finds fulfillment in these. The thought of doing away with women comes to him 'like an animal on a local anesthetic' (p.11). It may make him feel as though he has ceased to exist if he entertains such ideas.

After the incident at St George's Street and the subsequent walk away of Soraya from their illicit affair, he begins to feel threatened. He has such a hard time accepting that Soraya does not want to see him anymore: "For a man who believes that a woman's beauty does not belong to her alone. It is part of the bounty she brings into the world. She has a duty to share it (p. 16).

David Lurie's white traditional masculine orientation teaches him to assume that women exist for man's pleasure. In the above extract, he is immediately characterized as a man who believes that he has the right to possess women's bodies without responsibility towards them or respect for their lives. He asserts his individual sexuality over and above the mutual love that needs to exist between a man and a woman. No wonder he is bent on usurping Melanie's body; his sexual orientation is linked to a sense of authority and entitlements. This prejudice is what later prevents him from reasoning with the Committee of Inquiry because he sees his actions as defensible. Lurie becomes intoxicated with Melanie, wanting to over-power her with all his fixated strength.

His affair with Melanie takes a different turn. It is important to acknowledge that the notoriety in Lurie's behavior divulges racial issues that are worth our attention. Appearing before the Committee of Inquiry, David Lurie seems to be contesting the new state's ideology. Lurie is accused of having a sexual relationship with his student and he is called to appear before a committee of inquiry to plead his case. At this point, he does not even want to read the statement brought against him by Melanie and he refuses a compromise and a public apology. As a white South African male, Lurie sees the demands of the committee as preposterous possibly because they want him to confess to something he really does not consider as out of place. His obstinate attitude also finds meaning in the fact that he thinks he owns Melanie not just as a woman but as a person belonging to a minority group; a person whose abuse is 'legitimate' and therefore, showing remorse or demonstrating the sincerity of his statement means overturning the status quo.

The history of exploitation that clouded the apartheid era, where white South African men in particular constructed their masculinities in relation to the ways that they perceived women and men of colour (Epstein, 1998), made men beneficiaries of sexism and therefore David Lurie's uncompromising attitude at the hearing as juxtaposed to the public hearings of the Truth and Reconciliation Commission (TRC) reveals the limited attitudinal change of many white South Africans who continue to think that the apartheid past was not unjust. And so the committee's insistence on a public apology comes to Lurie as inherently problematic. The 
ambivalence in Lurie's submissions suggests that although he agrees to have defied his ethical responsibility towards Ms. Isaacs, he sees the core of the hearing as some kind of a witch-hunt to discredit him since he claims to have been used as a scapegoat and also that he is a person disliked by the chair of his department. He simply sees the hearing as discriminatory.

Indeed, the coincidence between Lurie's hearing and the Rape Awareness Campaign, which is intended to flush out the Casanovas in the university, is significant. It is a move used by the writer to deliberately stress the desire to cure and heal South Africa of the endemic violence that has engulfed it. Again, the committee's demand for Lurie to make a public statement, even though he refuses, corroborates the extent to which the desire for a new South Africa becomes evident. The committee's demand for a public statement means an open declaration of remorse, a repentant gesture and a move for reformation. This move of reformation as is embedded in the public declaration constitutes a promise to do things anew and a desire to work out a compromise.

But, Lurie's refusal to accept the committee's demand is not simply because he is not regretful; it is because he sees the proceedings as witch-hunt. Be that as it may, we realize that at any rate, he is prepared for a reasonable compromise suggesting his desire to alter his existing world. In a conversation with Lucy, Lurie's daughter:

'Rose said the atmosphere was nasty',

I brought it upon myself. I was offered a compromise, which I wouldn't accept'.

'What kind of compromise',

'Re-education. Reformation of the character. The code word was counseling.'

'And are you so perfect that you can't do with a little counseling'

'It reminds me too much of Mao's China. Recantation, self-criticism, public apology. I'm old-fashioned, I would prefer simply to be put against a wall and shot. Have done with it'.

'So you stood your grounds and they stood theirs. Is that how it was'

'More or Less' (p. 66).

It is evident that Lurie is a hangover from the past. He believes in the apartheid system and the privileges it offers to the whites in South Africa which includes owning the bodies of women. And so accepting the compromise means denying his faith in the apartheid system as well as denouncing his privileges. Lucy's question: 'And are you so perfect that you can't do with a little counseling' becomes crucial. Would Lurie have been less a man or less white if he accepted the compromise? It is important to recognize that the endemic nature of segregation (expressed through binaries; black/white, master/slave, male/female) has restricted any willingness for change. And therefore, accepting the compromise means disrupting his self-identity. But his mind has become 'a refuge for old thoughts, idle, indigent with nowhere else to go' (p.72). Lurie sees the bit of public apology as hypocritical and self-deception because he intimately believes in the foundations of his superior identity. For him his actions are justified and therefore there is no need to settle for a compromise. He still wants to hold on to the foundations of his authority. He is determined on being 'bad' and even 'dangerous'. He is not prepared to change. His masculinity finds superiority in the privileges the apartheid system offers the white men in South Africa and he will not redefine his masculine identity despite the move to democratic rule.

David Lurie is an orthodox male. His beliefs, attitudes and traits find meaning in the dynamics of the apartheid system which is why he considers himself better than anyone. Several attempts at persuading Lurie to re-think his masculine identity are frustrated by his own 
insistence on remaining 'superior'. Like Adichie, Coetzee also plays on the relationship between space and masculine transformations. Lurie's change in location, dethrones him from a superior position to a shameful one. He reconsiders his masculine ideologies rather too late and so the opportunity of becoming a better person is scrapped by his stubborn arrogance as white South African male. On the other hand, Petrus is a black peasant, a gardener and the 'dog-man on Lucy's Small Holding in the Eastern Cape. He has two wives; one in Adelaide and the other stays with him on the farm. He obviously has a liking for women because of how he carefully schemes to have Lucy, Lurie's daughter as his third wife:

Ask him. I'm sure he will. He got a Land Affairs grant earlier this year, enough to buy a hectare and a bit from me. I didn't tell you. The boundary line goes through the dam. We share the dam. Everything from there to the fence is his. He has a cow that will calve in the spring. He has two wives, or a wife and a girlfriend. If he plays his cards right he could get a second grant to put up a house; then he can move out of the stable. By Eastern Cape standards, he is a man of substance (p.77).

In Lucy's estimation, Petrus is an accomplished man. Working with him as her dog-man and farm manager, she has come to appreciate his commitment to succeed. This is Petrus. He is 'the man' in his own circles and yet he wants to be something more -more of a privileged man just like the white South African males. He has a dislike for white supremacy; Petrus finds it distasteful to consider Lucy his benefactor and so despite his achievements as a black man, he cannot help but feel frustrated about this pathological phenomenon of inferiority complexes:

Petrus chuckles, 'No, it is a skill job, building, he says, 'bricklaying, plastering, all that, you need to be skill. No, I am going to dig the trenches. That I can do by myself. That is not such a skill job. That is just a job for a boy. For digging you just have to be a boy (p. 112).

Considering himself a 'boy' reveals his lack of self-confidence, inferiority complex and a feeling of frustration that continue to haunt him as a black South African male. The only means by which he can imagine himself becoming 'the real man' is to apply brute force and usurp the small holding of Lucy and subsequently become the farm manager. He masterminds the gang rape of Lucy and subsequently proposes to make her one of his wives. As Fatton (1986) observes, the struggle against white supremacy by the blacks in South Africa is premised on the need for interracial linkages such as mixed marriages and so Petrus's real intentions are to dilute the phenomenon of idolizing white men and women and to assert for himself a new identity.

Petrus is a chauvinist with a domineering personality. He considers women as secondclass citizens who need to be directed lest they stray; a good reason 'for putting Lucy in her place' (p.129). His sense of masculinity is tied to the history of black resistance to white conquest and white dominance and so the success of the raid brings him some relief. He admits that 'No more dogs, I am not any more the dog- man' (p.129). He supposedly conquers his fears. He begins to entertain the possibility of being in charge. No more dogs, no more a boy but a farm manager, a 'real' man.

Petrus's masculine identity can be described as cacodox. He has stringent but erroneous opinions about what it means to be 'the man'. This is because, despite Lucy's praise of him as being an embodiment of respectable maleness as far as Eastern Cape standards are concerned, he feels a sense of limitation because of the racial dynamics in South Africa. He determines to consciously get into a more respectable domain of maleness; his association with the incursion on Lucy's small holding allows him to carve for himself some kind of a prestigious identity as a 
male. However, Petrus cannot be described as an orthodox male because of the dim segregation in South Africa. In the world of Coetzee's Disgrace, orthodoxy is tied to white supremacy and it appears an impossible achievement for Petrus. Nonetheless, Petrus achieves to an extent a degree of orthodoxy when he coerces Lucy into a mixed marriage. Their (Petrus and Lucy) union point to a new generation that stands the possibility of neutralizing the racial segregation in South Africa.

'This place called South Africa': Spaces of Shame and Pride

The notions of place and space are often used interchangeably. They are often conflated and their agency can be referred to collectively as spatial processes. Spatial politics has become an important construct for critical consideration since it continues to be subsumed by its affiliate concept of time (Upstone, 2009). Key thinkers of spatiality (Foucault, 1986; Harvey, 1996; Soja, 1996; Lebefvre, 1991) have connected and disconnected the politics of space with temporality and historicity.

For instance, Upstone (2009) claims that a re-assertion of spatiality requires temporality as a factor of equal significance. Spatial dynamics in contemporary times is not simply a reinscription of history; it is also a means of exploring the anticipatory ideas that hitherto were opaque in matters relating to new times in the politics of Africa's future. A new spatial dynamic in the context of this project means a redefinition of relationships in terms of how new forms of subjectivities and inter-subjectivities emerge in qualitatively improved spaces. This is because space in itself has inbuilt dynamics of oppression in terms of subordinate and super-ordinate relationships and so the production of space must be allowed to showcase itself (independent of time although essential) in terms of its varied properties. Our emphasis on space is limited to the physical spaces of Cape Town and the Eastern Cape as presented in the novel.

Cape Town plays two symbolic functions: Prejudice and as a site of patriarchal expression. The prejudiced politics of discrimination has become so pervasive that all forms of abuse including the abuse of women (especially black women), forceful eviction of non-white citizens and ethnic and racial groups have become part of the embraced values of the people. Indeed, the core of the social values in Cape Town places men above women. Women are seen as the new 'other' with black women as a more hopeless category. Therefore, the abuse of women is no crime at all. That is why David Lurie sees the stance of the commission of inquiry as absurd and comical. For Lurie, a woman's body does not belong to her alone (p.16) and so Melanie (his female student) has a responsibility of sharing this beauty. Thus, his affair with Melanie is 'justifiable' - he was merely taking what is rightfully his. He has the right of desire (p.89). This prejudiced racial history; the idea of ownership and superiority and the biased nature of the political climate in Cape Town deny Lurie the opportunity to recognize his imperfections as a white man.

Again, part of Lurie's indifference towards the commission of inquiry is because issues of sex and rape are private matters. The usual nature of such gendered violence restricted any form of public retribution which is why the commission's demand for a public apology appears exaggerated to men like David Lurie. Lurie is unable to identify with this demand because it deviates from the 'accepted' practice. He shrugs: "These are puritanical times. Private life is public business. Prurience is respectable, prurience and sentiments" (p. 87). 
Cape Town is symbolic of patriarchal repression. In Cape Town, we find that the abuse of women is almost a natural phenomenon - something permissible and so it is not surprising the cunning ways Lurie's male colleagues appear to devalue the severity of the crime he commits. Their show of solidarity in his hearing simply suggests that there is nothing unusual about his (Lurie) behavior (52). It is important to recognize that the concurrence of Lurie's hearing and the rape awareness campaign is significant in terms of calculated attempts at debasing such patriarchal definitions.

When David Lurie moves to the Eastern Cape after his expulsion from the University, he appears to find the setting and the pre-occupation of the people who live there repressive. Starting with Petrus and the Shaws, Lurie has a difficult time accepting them as his daughter's friends. Because, like he has always wanted for Lucy, they are not capable of taking her to a higher life - a life worth living. He desires for her a life better than just farming and rearing dogs. David's definition of a higher life is premised on his taste for sophistication; something out of the reach of the blacks because of the forced physical separation between the races in South Africa. When Lucy talks her father into accepting to work with Petrus and the Shaws', we find in his resistance a certain displeasure that is shaped by historical antecedents. For Lurie, offering to help with the dogs and the farm was absurd, a dubious reversal, it sounds like someone trying to make reparation for his or her past misdeeds (p.77).

In a conversion with Lucy, Lurie admits that:

Alright I will do it. But only as long as I don't have to become a better person. I am not prepared to be reformed. I want to go on being myself. I'll do it on that basis ... understood?

So you are determined to go on being bad. Mad, bad and dangerous to know. I promise, no one will ask you to change (p.68).

Becoming a better person means being reformed, to change one's worldview. It means accepting to live according to the expectations of the new political dispensation in South Africa. $\mathrm{He}$ is not ready for a change. He still wants to live in the present as though he lived in the past. $\mathrm{He}$ is bent on being 'dangerous' and no one will compel him to reconsider. Before he could know it, his white orthodox masculine tendencies begin to give way for a more reformed masculine identity. It was a difficult, gradual, and a painful awakening. He begins working as Petrus's assistant - something he never envisaged. He becomes 'a boy' because he falls out of grace and while he is learning to re-adjust to his new life, Lucy is raped. It is important to recognize why Lurie is particularly affected by Lucy's rape. He is not only affected because he is not able to go to her rescue when she obviously needed it, but his trauma finds meaning in Lucy's continued obstinate attitude not to bring her rapists to justice. Even though Lucy's position may seem weird in the context of the racial politics in South Africa, it is also important to recognize the negative results of publicizing rape as a framework of abuse.

Notwithstanding these orientations, Lurie reads his daughter's position as unimaginable, unspeakable and for the most part torturing since it appears a way of abetting a historical crime as huge as violating a white woman's body. As Graham (2002) rightly observes, Lurie sees a history of wrong in Lucy's rapists but he is blind to the history of exploitation in his own behavior. Coetzee's apparent reason for such depictions is not to rule out the operations of memory in looking forward, but what he seems to be doing is to ridicule the laws that permit black subjugation and advocating for equality of the races. Lurie is allowed to have a feel of 
what it means to be abused, a preparatory move to rethinking his perceptions of the blacks and a move to an inward reformation.

What Lurie wants to prevent is for Lucy to have a baby which will be regarded as inferior per the problems of mixed marriage in South Africa. In 1949, white South Africans could not marry blacks because it was banned under the Immorality Act. It became the first major piece of apartheid legislation. In 1950, there was a ban on mixed marriages and extra marital sexual relations between white and black South Africans. Sex between white and other ethnic groups was now a criminal offence and so the move by Petrus to marry Lucy further cripples Lurie psychologically. He cannot understand Petrus' audacity and the fact that Lucy is also not helping matters with her attitude. For him, it is criminal for Petrus to have planned the rape and at worse offering to marry her and also making her a second wife:

Just an after-effect, he tells himself, an after-effect of the invasion. In a while, the organism will repair itself and the ghost within it will be my old self again. But the truth he knows is otherwise. His pleasure in living has been snuffed out like a leaf on a stream, like a puff balloon, a breeze; he has begun to float towards his end. He sees it quite clearly and it fills him with (the word will not go away) despair (pp. 107-8).

The after-effect of the invasion overwhelms his reasoning. He tries very hard to deny his desire to make amends; he becomes a handlanger to Petrus (p.136), a mere assistant to a black peasant. He begins to feel an outsider - he no longer recognizes himself and subsequently begins to smell shame all around him. He becomes a dog-man, a dog-undertaker, a dog psycho pomp, a harijan (p.146). The comparison Coetzee sets between Lurie and the harijan reveals how insignificant Lurie has become. He had fallen from being a privileged white man to becoming a person of the lowest social and masculine status. He takes over as 'the boy'. The altered worlds that Coetzee presents through the characters of Petrus and Lucy are intimations of a better tomorrow in South Africa; an age where there is a reversal of historical and political facts through the very apparatuses that favoured them. A new spatial dynamics is also seen through the overturned spatial segregation and land dispossession expressed through the relationship between Petrus and Lucy.

The 1913 Land Act designated land on a racial basis and prohibited purchase or transitory of land rights by Africans outside of demarcated reserves (Hall, 2010). Twenty years after the end of apartheid, land ownership in South Africa is still skewed along racial lines; land policy formation continues to be shaped by racial patterns. As Moya (2004) observes, the black populace continues to remain marginalized in the distribution of lands and other natural resources. The question of ownership, taking into accounts the role played by this racial framework, has resulted in several land reforms including the three-pronged programme of land reform provided in South Africa's Constitution of 1996. As per this provision: "A person or community disposed of property after 19 June, 1913 as a result of racially discriminatory laws or practices is entitled to the extent provided by an Act of Parliament to restitution of that property or to equitable redress" (RSA, 1996a, Section 25(7)).

Despite the controversies surrounding these reforms, Coetzee suggests a robust progress with land reforms and how it can contribute to stabilizing the political atmosphere in postapartheid South Africa. In the world of Coetzee's Disgrace, we find that after the gang-rape of Lucy, she becomes mistrustful of the environment in which she lives even though she could count on her dog-man (Petrus). She realizes that Petrus's marriage proposal is just what she 
needs, taking into account her circumstances. It is not to say that she does not care about the discomfort it will cause her father, nor the extent to which her acceptance will compound the problems already associated with mixed marriages. Rather, her need for protection in an environment which has become hostile compels her to ignore the painful humiliation in becoming a third wife to a black peasant. She readily acknowledges this hard truth. She says:

Yes, I agree it is humiliating. But perhaps that is a good point to start from again. Perhaps that is what I must learn to accept. To start at ground level. With nothing. Not with nothing but with nothing. No cards, no weapons, no property, no rights, no dignity... Yes, like the dog (p. 205).

Lucy's humiliating acceptance of Petrus's proposal finds meaning in her desire to unite and bond with the peasants to form a new community. Her willingness to give up her lands and the desire to become a 'by owner' and a tenant on her very own lands are indicative of the desire for a new beginning. Rather than continue to see each other as separate racial bodies, Lucy preaches inclusion, restoration, communism and equity, all at ground level. What Coetzee suggests is the fact that racism may truly end if political actors and policy makers make an effort at creating a level ground for both whites and blacks primarily in the exercise of their fundamental human rights. In other words, a genuinely new South Africa requires a reorganization of the spaces of shame and pride.

Cape Town is a space of pride and yet very dangerous. David Lurie sees everything in his reach as meant for his use, including Melanie, because of the White superiority that reigns in Cape Town. Which is why he is adamant in making any public apology; neither is he willing to reach a compromise nor opt for counseling upon the demand of the disciplinary committee. It is indeed ridiculous because he forms part of the dominant apparatus- the owners, the ruling class and the superiors. It is more of a private space. Everyone lives as it pleases them regardless of the new order - the abolition of the apartheid system. And so when David Lurie is eventually expelled from the university, he realizes that the privileges of Cape Town are gradually becoming weak. Private business becomes a matter for public concern and therefore he is unable to recognize his environment. It is a new dispensation and it has become a threat to his identity as a white South African male.

The Eastern Cape is certainly a space of shame and yet it becomes a space of refuge and of hope. It was a no-life environment, very repressive for a man of Lurie's status. When he finds himself in the Eastern Cape, he thinks of extending to that space the dangers of Cape Town. He looks down on everyone there except Lucy his daughter. After Lucy's gang rape incident, he gradually and strangely begins to delight in the things he earlier on considered as humiliating. He no longer insists on remaining a dangerous person because he no longer has 'dignity', no more privileges; he becomes just a 'boy', the dog -man, a handlanger. He is gradually relieved from his old ways. The Eastern Cape saves Lurie from himself. His experiences with the Shaws' and Petrus pull him out of history and though he becomes less the man he used to be, he obviously becomes a better person.

For Coetzee, the new South Africa will only be stabilized in terms of racial tensions if only persons like David Lurie (who represents the voice of the Whites in South Africa) are able to learn to accept no privileges, no rights, no property and no cards in order to make way for equity; a very distasteful necessity for re-building South Africa. It is important to recognize that Lucy's desire to redefine dignity just like the dog is highly significant as far as the new South 
Africa is concerned. Petrus's treatment of Lucy and her father at his party reinforces this. He does not play the eager host, does not offer them a drink (p.129). It is just like saying that you are no strangers (foreigners) and so you may help yourselves if you so wish. Surprisingly, Petrus says: 'No more dogs. I am not any more the dog-man' (p.129).

At this point, Petrus begins to see himself as the master. He is soon going to be the 'owner' of the owner of the dogs he has been caring for (a plan he will achieve should Lucy accepts his proposal) and therefore he sees himself as having equal or enough dignity as his benefactor. The disconnect in Lurie's acceptance to become a dog-man (owning no dignity) and Petrus's excitement at being not any more a dog-man reconciles in terms of re-instating the status quo. It is a move to reconstructing masculine behaviours as well as refiguring hope in a politically charged arena.

The overturned desires (as demonstrated through Petrus' and Lurie in terms of the reversals in wielding power) help us in our appreciation of what a new South Africa holds for the contending racial groups. It is important to recognize that the new South Africa, as it is conceptualized in Coetzee's Disgrace will be distasteful for the white minority and a pleasant beginning for the black populace. However, the new South Africa can be a better community if only the White minority will redefine humiliation as a call for inclusion. The reversal also shows the nervousness with which the subordinated racial groups impatiently anticipate a better community where there is no segregation, stratification and subtle subordinations. Coetzee's complex interrogation of the relationships that exist among characters in his novel forms part of the anticipatory project which makes room for racial assimilatory practices. Rather than a direct interrogation, Coetzee creatively subverts racially defined notions in order to make way for a better appreciation of the deed done by apartheid to certain groups of people.

The spatial climate in Disgrace becomes somewhat hazy in terms of the generated feelings of remorse, anxiety and uncertainties arising as a result of the upturn dynamics of space. While it is important to recognize the fundamental difference in the state of affairs in postapartheid South Africa and the anticipated new South Africa, Lurie's eventual awakening suggests a potent route through which we arrive at our visions of the new South Africa which is also carefully represented through Lucy and Petrus. The transition is represented in the change in power dynamics of groups that are solely dominated or subordinated in the shift of material wealth.

\section{Refiguring Hope and Desire: Masculinities in Transition}

Desire, generally speaking, is a strong feeling of wanting to have something or wishing for something to happen or the sense of longing for or hoping for something or an outcome. Eldrege (as cited in Ian-Cheng, 2013) claims that: 'there is a secret set within each of our heart. It is the desire for life as it was meant to be' (1). In other words, desire is produced as a result of an inner motivation; what is good and preferable in order to make up for what has been lost or not yet attained. In the contest of this paper, desire is not simply what human beings lack and seek for but also the valuable generated efforts at reaching this need. Therefore, the desire for reaching the new South Africa, as I argue, is contingent on the individual as well as the collective efforts of both racial groups - in terms of arriving at a common definition of the preferred civilization. 
In much the same vein, hope points to a feeling of optimism or the desire that something will happen.

As Bloch (1995) observes, all human beings dream of a better life and that these dreams are impulses of desire for perfection. He maintains that these impulses are provoked by one's lived experiences and for that reason, have a profound future orientation. Disgrace's transformative potential consumes the uncertainties of a better community yet to come. Indeed, the aging process of transiting from grace to disgrace as exemplified through the experiences of Lurie signals the desire at attaining what seems to be impossible.

Lurie's conscious change from his past life communicates a progression from 'where we were not' to 'where we have come to be' and therefore deepens the pursuit for a new community and here in our case, a new South Africa. It is important to recognize the fact that Lurie's painful awakening becomes possible upon his arrival in Grahamstone (Eastern Cape) (as the repressive space) and the subsequent rape of Lucy. Rather than limiting him in terms of ambitions, Grahamstone becomes that special place for reflection - the renewed space, containable; where the operations within this landscape compels new meanings for personal and inter personal relationships and thus indicating the potential of a new civilization. The rigid civilization proposed by apartheid is reconfigured through the function of desire.

We also find in Petrus's character an impatient desire to belong to the preferred community demonstrated through his ambition to 'own' Lucy and her property. Despite the racial hostility, the mutual fear shown by both Lurie and Petrus is indicative of their individual dilemmas of what this new community holds for them. Petrus's desire for status and to possess, however contentious, increases the level of tolerability between the two racially defined groups. This mutual need compels Lucy to sacrifice her body as a means of lowering the weight of the historical guilt. Their proposed union restores some sort of racial harmony. Their negotiations further serve as a rich means to stop gendered rifts that may arise in their new life and by extension, fortifying the foundations of this new civilization that awaits them and providing a conducive climate for the operations of gender. Although Petrus's intimate desire for status may be read as a patriarchal tendency to possess a woman's body and the usual move for dominance, the question of no more being the dog-man (just like Lurie's giving up on the dog) becomes significant.

Coetzee's vision of life in post-apartheid South Africa is clearly demonstrated through the ways in which space is re-organized in the text. For Coetzee, a new civilization, which is what is required, will mean a calculated effort to consciously upturn the centre of power operations in order to accommodate subordinated groups. This paper has demonstrated how Coetzee's Disgrace contributes to the discourses on emerging masculinities taking into consideration the history of South Africa. The paper has examined the characters of David Lurie and Petrus in order to define the characteristics of the new man in contemporary African fiction. This rereading of Coetzee's Disgrace shows that there is a connection or relationship between masculine representations and the spatial dynamics in the text.

Although there is no explicit statement on futurity, the correlation between masculine representations and spatial re-organization proposes alternatives that are crucial in our attempts at envisaging a new South Africa. It has shown that the new South Africa may come to stay if only white superior ideology (represented in the character of David Lurie) give way to a more inclusivist mode of being. Like Jaja in Adichie's Purple Hibiscus, Coetzee's Disgrace represents 
the portrait of the new man in both Lurie and Petrus. With Lurie, Coetzee appears to suggest that the new man must be critical of his heritage so that he can assume a refined personality that in itself is indicative of progress. Although Petrus's approach in re-defining his masculine identity is somewhat brutish, his determination at undoing the inferiorities is significant.

His resolve to be recognized as an accomplished man despite the history of segregation remains a quality of the new man. The characterization of violence parallels feelings in postapartheid South Africa where evil does not belong to the 'other' alone. It is a means by which the marginalized reclaim their stake in the economy and register their disapproval in a society that has denied them of several privileges, which is why Lucy refuses to report her rape to the police because she felt that; 'They see me as owing something. They see themselves as debt collectors. Why should I be allowed to live here without paying?' (p.36). Thus, Petrus's brutish behaviour is symbolic of the political freedom that had come to South Africa.

\section{Conclusion}

Contrary to the claim that Coetzee's Disgrace is unenthusiastic about the New South Africa (Kok, 2008; Opheim, 2016), the paper assessed Coetzee's re-visions of the New South Africa through a re-examination of his male characters. The paper was structured into three main parts. The first section looked at how Disgrace, a novel set in the post-apartheid era, re-examines the intimate historical issues and the extent to which these facts become defining as far as our visions of the New South Africa is concerned. In the second section, I looked at Coetzee's construction of acceptable maleness in a racially charged society. I focused on the character of violence as symptomatic of postcolonial maleness. While both Lurie and Petrus use violence to signal their male power, it is evident that Petrus' use of violence is constitutive of his desire for change and newness. The third section of this paper discussed how issues of space engineer redefinition of relationships in terms of how hierarchical structures are demolished for communal effect. We realize that Lurie's eventual transformation is shaped by the spatial climate in the Eastern Cape and the fact that his superior ideologies are gradually dispelled by his new circumstances. The final section, summarizes the overall argument of the paper. 


\section{References}

Achebe, C. (1958), Things Fall Apart; Heinemann, London Anderson, T. (2007), In Control or in Despair: Protagonist Analysis of David Lurie in Disgrace and Okonkwo in Things Fall Apart; Sodentoms University College

Ashcroft, B. (2007), "Forcing Newness into the World: Language, Place and Nature" Ariel vol. 36, 1-2 (Jan-April 05) pp. 93-110

Ashcroft, B. (2007), “Critical Utopias” Textual Practice 21 (3), pp. 411-431

Ashcroft, B. (2009) "Remembering the Future: Utopianism in African Literature" Textual Practice 23(5), 2009: 703-722

Ashcroft, B. (2009), "The Ambiguous Necessity of Utopia: Post-colonial Literatures and the Persistence of Hope" Social Alternatives 28 (3): 8-14

Ashcroft, B. (2009), "Beyond the Nation: Post-Colonial Hope" JEASA (Journal of the European Association of Studies in Australia): 12-22.

Ashcroft, B. (2012) "Introduction: Spaces of Utopia”,Spaces of Utopia: An Electronic Journal, (Special Issue: Postcolonial Utopianism) 2nd series, no. 1: pp. 1-17<http://ler.letras.up.pt > ISSN 1646-4729.

Ashcroft B. (2013) African Futures: the Necessity of Utopia. International Journal of African

Renaissance Studies8(1): 94-114 
Attridge, D. (2002), Age of Bronze, State of Grace: Music and Dogs in J. M. Coetzee's Disgrace, Novel: A Forum on Fiction. 34.1: 98-121

Attwell, D. \& Harlow, B. (2000), Introduction: South African Fiction After Apartheid. Modern

Fiction Studies 46. 1:1-9

Benard, R. (2003), J.M Coetzee's Disgrace and the South African Pastoral. University of

Wisconsin Press

Bhahba, H. (1994) How Newness enters the World: Postmodern Space, Postcolonial Times and the Trials of Cultural Translation. The Location of Culture. London and New York, Routlege. Pp. 212-234

Bloch, E. (1995). The Principle of Hope; MIT Press, Cambridge, Mass

Bradford et al (2008), New World Order in Contemporary Children's Literature. Utopian Transformations, Palgrave Mc Milan, New York

Brandon, H. \& Gunner, T. (1998), A State of Denial: White South Africans' Attitudes to the Truth and Reconciliation Commission. Indicator, South Africa, 15 (1), Autumn, pp. 8-12

Burke, P. J. \& Stets, J. (2000), Identity Theory and Social Identity Theory. Washington State University

Butler, J. (1999), Gender Trouble: Feminism and the Subversion Of Identity, Routledge, New York and London

Butler, J. (1986), Sex and Gender in Simone De Beauvoir's The Second Sex; Yale French Studies No 72

Coetzee, J. M. (1999), Disgrace, Penguin Groups. New York

Chou, K. (2009), 'This place being South Africa': Reading race, sexual power in J. M. Coetzee's Disgrace. University of Michigan

Croux, M. (2005), Presentations of Masculinities in A Selection Of Male-Authored PostApartheid Novels. University Of Stellenbosch

Du Pisano, K. (2001), Puritanism Transformed Afrikaner Masculinities In The Apartheid And Post-Apartheid Period In Morel, R. (2001); 157-176

Epstein, D. (1998), Marked Men: Whiteness and Masculinity. Agenda 37:49-59

Foucault, M. (1984), Of Other Spaces: Utopias and Heterotopias. MIT Press

Graham, L. (2003), Reading the Unspeakable in J. M. Coetzee's Disgrace, Journal of Southern Africa Studies 29.2:432 - 444

Hall, R. (2004), A Political Economy of Land Reform in South Africa, Review of African Political Economy No. 100:23-37, ISSN 0505-6244

Hawkins, F. (2015), Reading the Golden City: Spatial Representation and Urban Semiotics in the Works of Ivan Vladislavic. Queens's University, Kingston, Ontario - Canada

Hyatt, M. C. (2006), No-Where and Now-Here: Utopia and Politics from Hegel to Deleuze; University Of Southern California, ProQuest Information and Learning Company, USA Ian-Cheng, Y. (2013), Desire and Its Discontent in J. M. Coetzee's Disgrace. Soochow University

Karwoska, K. (2013), Literary Spaces in the selected works of J. M. Coetzee; Silesian Studies in Anglophone Culture and Literatures 2. Peter Lang Edition

Kochin, M. (2002), Post Metaphysical Literature Reflections on J. M. Coetzee's Disgrace. Lectures Delivered At 2002 Annual Meeting of The American Political Science Association. Kok, M.S (2008), An Investigation of Masculinity in J. M. Coetzee's Disgrace, Nelson Mandela 
Metropolitan University

Lebebrre, H (1991), The Production of Space, Malden, MA: Blackwell

Nnolim, C.E. (1988), Ridentem Dicere Venum, Literature and the Common Welfare. An

Inaugural Lecture delivered at the University of Port Harcourt

Opheim, K. M. (2016), J. M. Coetzee's Disgrace: At the Margins of the Human, University of Bergen

Patton, P. (1986), Becoming Animal and Pure life in J. M. Coetzee's Disgrace

Perchey, G. (1998), The Post-Apartheid Sublime in Attridge, Derek and Rosemary Jolly: 57-74

Ricoeur, P. (1986), Lectures on Ideology and Utopia, Ed. GH Taylor: New York. Columbia

University Press

RSA (Republic of South Africa) (1996), Constitution of the Republic of South Africa, No. 108 0f 1996, Government Printers: Pretoria

Sallat, T. (1993), Dreams of Dusty Roads; Boulder, Co Three Continents

Sakamoto, T. (2013), Exploring Spatial Dynamics in Civil Conflicts in Virtual Africa: A New

Research Design. Center For Documentation of Refugees and Migrants (CDR) The

University of Tokyo

Soja, E. (1996), Third Space: Journey to Los Angeles and Other Real and Imagined Places, Blackwell Publishers Inc: Cambridge, Massachusetts, USA

Smith, S. J. (2015), 'Placing the Farm Novel: Space and Place in female identity formation in Olive Schreiner's The story of an African farm and J. M. Coetzee's Disgrace. North-West University, Potchefstroom

\section{Notes on Author}

Christabel Aba Sam is a PhD student in the Department of English of the University of Cape Coast, Ghana. Her areas of specialization include Masculinity Studies, Postcolonial Futures and Contemporary African Literature. She holds a Bachelors of Education (English option) and MPhil degrees from the University of Cape Coast where she currently works as an Assistant Lecturer in the Department of English. She teaches Gender and Writing, Aspects of Postcolonial Literature and Principles of Prose Fiction to undergraduate and graduate students. 